\title{
Comparison on Equity Investment Accounting Method Conversion of Old and New Accounting Principle
}

\author{
Jing Xu \\ Department of Accounting, College of Information and Business, Zhongyuan University of \\ Technology, Zhengzhou 450007, China
}

\begin{abstract}
Long-term equity investment accounting methods had cost approach and equity approach. The mutual conversion of the two approaches belongs to the change of accounting policy, which could be retroactive adjustment. This article profoundly introduced the six methods of two approaches' mutual conversion, and compared the difference of old and new accounting principle.
\end{abstract}

Keywords: long-term equity investment; the new and old accounting principle; cost approach; equity approach.

\section{Background and Objectives}

\subsection{Research Background}

In order to meet the requirement of the development of the socialist market economy, the Ministry of Finance printed and issued The Accounting Standard for Business Enterprises, No.2 - Long-term Equity Investment in circular finance and accounting No. 14 (2014). Meanwhile, it was annulled for The Accounting Standard for Business Enterprises, No.2 - Long-term Equity Investment in The Accounting Standard for Business Enterprises, No.1 - Inventory and related 38 items of specific principles in circular finance and accounting No.3 (2006) which was issued on $15^{\text {th }}$, February 2006. From $1^{\text {st }}$ July 2014, all the enterprises implemented the accounting standards for enterprises shall implement this standard. The overseas listed companies were encouraged to perform in advance. In addition, the revision was performed on The Accounting Standard for Business Enterprises, No. 22 Recognition and Measurement of Financial Instruments and The Accounting Standard for Business Enterprises, No. 39 - Fair Value Measurements and other related standards. New revised standards had certain influence on the accounting methods and accounting method conversion of long-term equity investment.

In addition, in the teaching process, the conversion of long-term equity investment was the difficulty of financial accounting and the knowledge point of students. There was no doubts that the revision of new standards and related principles could confuse the students who had learned this part, and impact the learning and understanding of consolidated financial statements.

\subsection{Research Objective}

In review of above mentioned new and old principles and issued related revised principles and problems in financial accounting learning, this study had a systematical description on long-term equity investment conversion through the comparison of long-term equity investment accounting method conversion in new and old principles. It enabled students had a systematical study and understanding on knowledge points, and facilitated the merger after the presentation of financial statements and reports after learned the knowledge.

\section{Specific comparison of Long-term equity investment accounting methods before and after conversion}

2.1 Brief introduction of the scope, method and summary of long-term equity investment under the rule of old and new principle

The conversion of long-term equity investment accounting method was mainly because the changes of long-term equity investment accounting scale and the following measurement of two methods content. The changes of the long-term equity accounting scale and the following two accounting method content under new and old principle, as shown in table 1. 
Table 1. Changes comparison of long-term equity accounting method content under new or old principles

\begin{tabular}{|c|c|c|c|c|}
\hline \multicolumn{2}{|l|}{ previous principle } & \multicolumn{2}{|c|}{ new principle } & \multirow{2}{*}{$\begin{array}{l}\text { changes of old } \\
\text { and new } \\
\text { principles }\end{array}$} \\
\hline accounting scope & $\begin{array}{c}\text { accounting } \\
\text { method }\end{array}$ & accounting scope & accounting method & \\
\hline $\begin{array}{l}\text { Subsidiary company investment } \\
\text { (shareholding ratio 50\% 100\%) }\end{array}$ & $\begin{array}{c}\text { cost } \\
\text { approach }\end{array}$ & $\begin{array}{l}\text { Subsidiary company } \\
\text { investment }\end{array}$ & cost approach & $\begin{array}{l}\text { without } \\
\text { change }\end{array}$ \\
\hline $\begin{array}{l}\text { Investment on cooperative enterprise } \\
\text { and associated enterprise (shareholding } \\
\text { ratio } 20 \% \sim 50 \% \text { ) }\end{array}$ & $\begin{array}{l}\text { equity } \\
\text { approach }\end{array}$ & $\begin{array}{c}\text { investment on } \\
\text { cooperative } \\
\text { enterprise and } \\
\text { associated enterprise } \\
\end{array}$ & equity approach & $\begin{array}{l}\text { without } \\
\text { change }\end{array}$ \\
\hline $\begin{array}{l}\text { don't have control, co-control or } \\
\text { significant influence on invested } \\
\text { enterprise, without quotation and fair } \\
\text { value on active market, unreliable } \\
\text { equity investment }\end{array}$ & $\begin{array}{c}\text { cost } \\
\text { approach }\end{array}$ & $\begin{array}{l}\text { other equity } \\
\text { investment }\end{array}$ & $\begin{array}{l}\text { recognition and } \\
\text { measurement of } \\
\text { financial assets }\end{array}$ & changed a lot \\
\hline
\end{tabular}

Table 2. Conversion change on old and new accounting principle of long-term equity accounting method

\begin{tabular}{|c|c|c|c|}
\hline \multicolumn{2}{|c|}{ Old principle } & New principle & Similar or same part of old and new principle \\
\hline $\begin{array}{c}\text { Cost approach } \\
\text { convert to } \\
\text { equity } \\
\text { approach }\end{array}$ & $\begin{array}{c}\text { A shareholding } \\
\text { ratio increasing }\end{array}$ & $\begin{array}{c}\text { C cost approach convert to } \\
\text { equity approach }\end{array}$ & Similar to B of old principle \\
\cline { 2 - 5 } & $\begin{array}{c}\text { B shareholding } \\
\text { ratio decreasing }\end{array}$ & $\begin{array}{c}\text { D fair value accounting } \\
\text { convert to equity approach }\end{array}$ & Similar to A of old principle \\
\hline $\begin{array}{c}\text { Equity } \\
\text { approach } \\
\text { convert to cost } \\
\text { approach }\end{array}$ & $\begin{array}{c}\text { I shareholding } \\
\text { ratio increasing }\end{array}$ & $\begin{array}{c}\text { E equity approach convert to } \\
\text { cost approach }\end{array}$ & Similar to I of old principle \\
\cline { 2 - 5 } & ratio decreasing & $\begin{array}{c}\text { F fair value accounting } \\
\text { convert to cost approach }\end{array}$ & Similar to I of old principle \\
\hline & - & $\begin{array}{c}\text { G equity approach convert to } \\
\text { fair value accounting }\end{array}$ & Similar to J of old principle \\
\hline & $\begin{array}{c}\text { H cost approach convert to } \\
\text { fair value accounting }\end{array}$ & No correlation to old principle \\
\hline
\end{tabular}

From table 1 accounting scope, new principle of long-term equity investment only calculated the investment on subsidiary company, cooperative enterprise and associated enterprise. The previous principle was calculated according to The Accounting Standards for Enterprises No.22 - Recognition and Measurement of Financial Instruments. It did not have control or co-control or significant influence on invested enterprise, and did not have quotation and fair value on active market, and did not have reliable accounting equity investment. The accounting method also had the corresponding changes. Due to the changes in above content, long-term equity investment accounting conversion also had changes. The change of old and now accounting principle was shown in table 2.

From table 2, in old principle, cost approach converting to equity approach due to decreased shareholding ratio and the equity approach converting to cost approach due to increased shareholding ratio were completely corresponding to the $\mathrm{C}$ and $\mathrm{E}$ of new principle, respectively. Other item had different degree of changes. In 2004, the revision of The Accounting Standard for Enterprises No. 30 - Fair Value Measurement and the revision of The Accounting Standards for Enterprises No. 22 Recognition and Measurement of Financial Instruments showed the attention of fair value measurement. It also expounded detailed the knowledge point in other principle involving fair value measurement. Long-term equity accounting method conversion was also the detailed introduction on fair value measurement, which was the great changes compared with old criterion. 


\section{2 specific comparison of long-term equity investment accounting methods under the rule of old and new criterion}

\subsubsection{Accounting method conversion types of old and new principle}

Under old principle, the accounting method conversion actually included four condition: A was the cost approach converting to equity approach due to shareholding increasing, B was the equity approach converting to cost approach due to shareholding decreasing, I was the equity approach converting to cost approach due to shareholding increasing and $\mathrm{J}$ was the equity approach converting to cost approach due to shareholding decreasing, which did not involve in other conversion introduction. These could be included in below Figure 1 left side. Accounting method conversion under new principle could be divided into six types, which were the right side arrow pointed $\mathrm{C}, \mathrm{D}, \mathrm{E}$, $\mathrm{F}, \mathrm{G}$ and $\mathrm{H}$, which were corresponding with the letter in table 2. New principle specially mentioned the conversion of fair value measurement and other methods. In below text, the financial assets took the examples of available-for-sale financial assets.

\begin{tabular}{|l|}
\hline \multicolumn{1}{|c|}{ Control (cost approach) } \\
\hline \begin{tabular}{|l|}
\hline common control, significant \\
influence (equity approach)
\end{tabular} \\
\hline $\begin{array}{l}\text { (cost approach) equity capital } \\
\text { investment without control, common } \\
\text { control or significant influence and } \\
\text { without quotation in active market and } \\
\text { without reliable measurement on fair } \\
\text { value }\end{array}$ \\
\hline
\end{tabular}

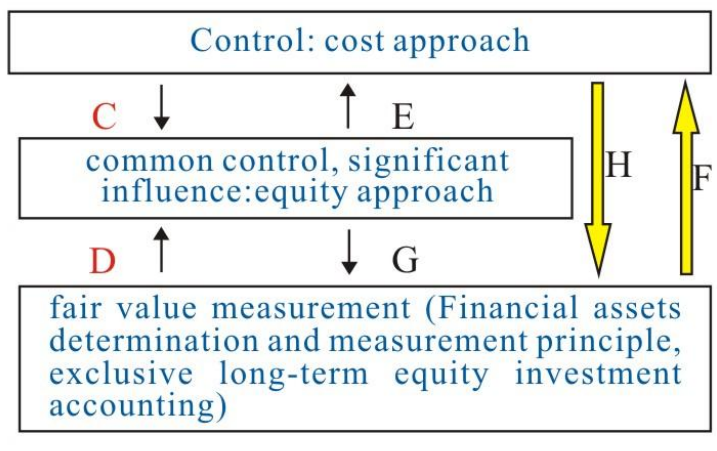

Figure 1 Comparison of long-term equity investment accounting method conversion type of old and new principle

From Figure 1, previous principle had four conversion methods, and new principle had six conversion method. The comparison of B and $\mathrm{C}$, and the comparison of I and $\mathrm{E}$ did not have change at all between the old principle and new principle. Although A and D, J and G had some similar part, it still had big difference. $\mathrm{H}$ and $\mathrm{F}$ were completely different added two conversion methods. The below accounting processing mainly explained the condition of B, C, D, E, F, G, H and I. A and J were not mentioned here. As under new principle, there was no conversion condition of $\mathrm{A}$ and $\mathrm{J}$.

\subsection{The condition of $B$ and $C$ in Figure 1: cost approach converted to equity approach due to capital decrease}

Firstly, cost approach was considered to deal with long-term equity investment proportion for accounting treatment. Secondly, the remained long-term equity investment cost was calculated according to balance shareholding proportion, and had the share of net identifiable assets fair value of original investment. If the former was greater than the latter one. Long-term equity investment book value was not adjusted; if former was less than the latter one, it shall adjust the long-term equity investment and retained earnings. Thirdly, the invested entity realization of net profit and loss during the original investment and investment treatment could be divided into two stage: the net profit and loss from original investment date to investment treatment date was adjusted the retained earnings; the net profit and loss in the latter time was adjusted the investment returns; In the other comprehensive income changes between original investment date and investment treatment date, it shall adjust both long-term equity investment and other comprehensive incomes; Other reasons lead to the invested entity equity share shall adjust long-term equity investment and capital reserves and other capital reserves. For example, Company A owned 60\% stake in the company B, the account balance is 90 million RMB, which shall be non-provision for impairment loss. On 6th May 2006, company A sold the $20 \%$ of shareholdings of company B to another company, the sale price was 54 million RMB. The total fair value of the identifiable net assets by the invested entity was 240 million RMB. Company A held the $60 \%$ shareholding of company $\mathrm{B}$. The fair value of company $\mathrm{B}$ identifiable net assets was 135 million RMB (assumed the fair value of the identifiable net assets and 
the account value were same). Since got the long-term equity investment, company B achieved 75 million RMB of net profit before the investment treatment date. Company An achieved net profit 6o million RMB from investment treatment data to early 2006. Assume that company B had not undertaken profit allocation, except the achieved net profit or loss, company B did not happen other transactions or events including in capital reserves. Company A took surplus reserves at $10 \%$ of the net profit. After sold the $20 \%$ shareholding, company a converted cost approach to equity approach for company B.

(1) The dealt $20 \%$ shareholdings:

Lend: bank deposit 5400

Loan: long-term equity investment 3000

Investment income 2400

(2) The remaining $40 \%$ long strands of book value was 60 million RMB. According to the remaining proportion of the original investment when the invested entity shall be accorded to the fair value for the identifiable net assets shareholding 54 million RMB (135 million by $40 \%$ ). There was no need the long-term equity investment.

(3) After the treatment, $40 \%$ of shareholding had the achieved profit or loss 30 million (7500 million by $40 \%$ ) from the start date to investment treatment date:

Lend: long-term equity investment - profit and loss adjustment 3000

Loan: profit or loss reserves 240

Profit distribution - undistributed profit 2160

Investment income 600

\subsection{The condition of $I$ and $J$ in Figure 1: equity approach converted to cost approach due to capital increase}

First, it shall assure the combining date of the initial cost of the long-term equity investment, the original cost of investment and new investment. Lend: long-term equity investment-cost. Load: bank deposit. Secondly, it shall adjust the consolidation date. Long-term equity investment was difference between the initial investment cost and the combing date. The entry was:

Lend: long-term equity investment. Capital reserves (or loan) was not enough to minus, then it was the retained earnings

Loan: long-term equity investment (cost, profit and loss adjustment and other equity changes). Then

Then, for the original investment solstice during the period of new investment, net profit or loss or distributing cash dividends or profits as well as other rights and interests of the adjustment of changes.

Lend: the retained earnings of investment income (or loan) was reserved when it was trans year.

Capital reserves (lend or loan) was not enough for minus, the retained incomes shall be taken. Loan: long-term equity investment (cost, adjustment of profit and loss, other equity changes, and other comprehensive income).

The condition of I and D in Figure 1: fair value accounting converted to equity approach due to capital increase.

Firstly, the long-term equity investment of initial capital cost was the fair value of available sale financial assets. Secondly, the difference between the fair value and book value and other comprehensive income cumulative changes included in the current investment income. Lend: other comprehensive income. Loan: investment income, or the opposite entries. Then, if the former was greater than the latter one. Long-term equity investment book value was not adjusted; if former was less than the latter one, it shall adjust the long-term equity investment and retained earnings. Lend: long-term equity investment - cost. Loan: the non-operation income (reserved income was used when it was Tran's year)

\subsection{The condition of $G$ in Figure 1: equity approach converted to fair value accounting}

First of all, according to the disposal of long-term equity investment to deal with the equity method.

Lend: bank deposit. The impairment of long-term equity investment 
Loan: long-term equity investment (investment cost, profit and loss adjustment. Other comprehensive income, other equity changes) investment income (or loan)

Second, the original investment solstice disposal, and other comprehensive income between capital reserves - other capital reserves to carry forward the current investment income.

Lend: other comprehensive income or capital reserves - other capital reserves

Loan: investment income or contrary entries

Then, the rest of the book value of long-term equity investment can be added into available for sale financial assets, available for sale financial assets with the disposal of the same day of the fair value accounting, and the difference between the book value of the long-term equity investment, included in the investment returns.

Lend: available for sale financial assets. The impairment of long-term equity investment

Loan: long-term equity investment (investment cost, profit and loss adjustment, other comprehensive income, other equity changes).

Return on investment (or loan)

\subsection{The condition of $F$ in Figure 1: fair value accounting converted to cost approach}

First of all, the transformation, the fair value of the equity investment plus the cost of new investment could be take as the cost of the long-term equity investment.

Lend: long-term equity investment

Loan: bank deposit. Available for sale financial assets (cost, fair value changes)

Second, the original fair value of the equity and the difference between the book value and the original changes included in the accumulated other comprehensive income shall be all accounted for as current profit or loss.

Lend: other comprehensive income

Loan: investment income or contrary entries

\subsection{The condition of $H$ in Figure 1: cost approach converted to fair value accounting}

First of all, according to the cost method under the long-term equity investment.

Lend: bank deposit

Loan: long-term equity investment. Return on investment (or loan)

Second, the proportion of the long-term equity investment converted into balance will be available for sale financial assets.

Lend: available for sale financial assets

Loan: long-term equity investment. Return on investment (or loan)

\section{Conclusion}

New accounting standard revision had great effect on the transformation of the accounting methods. The previous four specific transformation methods were revised to present six methods. This article profoundly introduced the method, connection and difference of old and new criterion through the specific introduction and its comparison of old and new long-term equity investment accounting methods.

\section{References}

[1] Xinfei Shentu. Variance analysis of old and new long-term equity investment criteria. Finance and accounting monthly. (2015) No. 1, p. 32-35.

[2] Xinfei Shentu. On increasing or decreasing in equity business accounting. Finance and accounting monthly. (2015) No. 16, p. 47-49.

[3] Yonghuan Yan. Long-term equity investment criteria revised accounting. Research of Finance and Accounting. (2014) No. 7, p. 41-42.

[4] Xiangyao Wang, Xianlong Zheng. Related comparison and perfecting suggestions of China long-term equity investment rule (draft). (2013) No. 25, p. 7-13. 